\title{
Depredation of Common Eider, Somateria mollissima, Nests on a Central Beaufort Sea Barrier Island: A Case Where No One Wins
}

\author{
John A. Reed ${ }^{1}$, Deborah L. Lacroix ${ }^{2}$, and Paul L. Flint ${ }^{1}$ \\ ${ }^{1}$ U.S. Geological Survey, Alaska Science Center, 1011 East Tudor Road, Anchorage, Alaska 99503 USA. Corresponding author \\ e-mail: paul_flint@usgs.gov \\ ${ }^{2}$ Centre for Wildlife Ecology, Simon Fraser University, 8888 University Drive, Burnaby, British Columbia V0R 1B0 Canada
}

Reed, John A., Deborah L. Lacroix, and Paul L. Flint. 2007. Depredation of Common Eider, Somateria mollissima, nests on a central Beaufort Sea barrier island: a case where no one wins. Canadian Field-Naturalist 121(3): 308-312.

\begin{abstract}
Along the central Beaufort Sea, Pacific Common Eiders (Somateria mollissima v-nigra) nest on unvegetated, barrier islands; often near nesting Glaucous Gulls (Larus hyperboreus). Nest-site choice likely reflects a strategy of predator avoidance: nesting on islands to avoid mammalian predators and near territorial gulls to avoid other avian predators. We observed a nesting colony of Common Eiders from first nest initiation through nesting termination on Egg Island near Prudhoe Bay, Alaska (2002 - 2003). Resident gulls depredated many eider nests, mostly during initiation. All nests failed when an Arctic Fox (Alopex lagopus) visited the island and flushed hens from their nests, exposing the eggs to depredation by the fox and gulls (resident and non-resident). Common Eiders actively defended nests from gulls, but not from foxes. Likely all three species (i.e., eiders, gulls, and foxes) ultimately achieved negligible benefit from their nest-site selection or predatory activity: (a) island nesting provided no safety from mammalian predators for eiders or gulls, (b) for Common Eiders, nesting near gulls increased egg loss, (c) for Glaucous Gulls, nesting near colonial eiders may have reduced nest success by attracting the fox, and (d) for Arctic Foxes, the depredation was of questionable value, as most eggs were cached and probably not recoverable (due to damage from fall storms). Thus, the predator-prey interactions we observed appear to be a case where little or no fitness advantage was realized by any of the species involved.
\end{abstract}

Key Words: Arctic Fox, Alopex lagopus, Common Eider, Somateria mollissima, Glaucous Gull, Larus hyperboreus, nest depredation, predator-prey interaction, Beaufort Sea, Alaska.

Along the central Beaufort Sea, nest success of Pacific Common Eiders (Somateria mollissima v-nigra) is highly variable, with egg depredation by Glaucous Gulls (Larus hyperboreus) and Arctic Foxes (Alopex lagopus) being the primary cause of nest failure (Johnson and Herter 1989; Johnson 2000). Common Eider nest-site choice on coastal barrier islands is thought to reflect a strategy of predation avoidance. Typically, Common Eiders nest in colonies, often within the territory of nesting gulls (Noel et al. 2005). By nesting on islands, Common Eiders may avoid mammalian predators such as foxes (Johnson 2000; Noel et al. 2005). By nesting near gulls, eiders may benefit from territorial defense by gulls (Bourget 1973; Schamel 1977; Götmark and Åhlund 1988; Fournier and Hines 2001), but may incur additional risk if the resident gulls depredate their nests. If the depredation rate exceeds the gulls' protective benefit, then Common Eiders could be experiencing an unsustainable situation similar to the "ecological trap" described by Dwernychuk and Boag (1972).

As part of a larger study of Common Eider breeding ecology, we conducted an intensive observational study of nesting biology on Egg Island, near Prudhoe Bay, Alaska. Our primary objective was to replicate the study by Schamel $(1974,1977)$ and document the behavioral interactions among Common Eiders and nest predators with minimal researcher disturbance.

\section{Methods}

We selected Egg Island for this study because data from annual surveys showed relatively consistent concentrations of Common Eider nests (Noel et al. 2005) and a similar observational study of Common Eider reproduction had been conducted there in the 1970s (Schamel 1974, 1977). Egg Island is a small unvegetated island that is part of the chain of barrier islands that form Simpson Lagoon (Noel et al. 2005). Prior to Common Eider nest initiation in 2002 and 2003, we erected elevated observation blinds near the main colony. In 2002, we used two blinds with $30 \mathrm{~m}$ above-ground plywood access tunnels, and in 2003 we used one blind with a $25 \mathrm{~m}$ access tunnel. The blinds were $1.2 \mathrm{~m} \times 1.2 \mathrm{~m} \times 1.5 \mathrm{~m}$ plywood boxes raised 2.5 $\mathrm{m}$ above the ground. Observers accessed the island in small boats, using the tunnels to hide our approach. Boating was limited to a single landing and departure per day and there was no observer activity on Egg Island outside of the tunnels and blinds. Common Eiders were never observed to flush while we accessed the blinds. However, the entrance of one tunnel in 2002 was near three Glaucous Gull nests. These gulls often flushed as we approached, but remained near their nest-site and returned to the nest quickly after we entered the blind.

With few exceptions due to poor weather, we recorded daily nest observations during blocks of $4-6 \times 1 \mathrm{~h}$ 
observation sessions. We staggered our observation blocks to cover the entire 24-hour period, because, at the latitude of our study site, the sun does not set during the entire nesting period. We conducted observations from initiation of the first eider nest until incubation at all nests terminated each year. During observation sessions, we mapped all nests within view of the blinds and recorded the amount of time each nest was occupied. We recorded all interactions with predators and, each hour, we performed 15 min predator watches during which we counted all aerial and ground patrols by avian predators. We tallied these counts to create an index of avian predation pressure.

We considered a nest to be a site in which at least one egg was seen or a site that was occupied by a hen during observations for $>24 \mathrm{~h}$. We considered incubation to have begun when a hen was seen on a nest full-time after at least three consecutive days of attendance. Nests were deemed failed when no eider was seen using the site on two consecutive days. Nests occupied $>24 \mathrm{~h}$ after an observed depredation event were counted as partial depredation, whereas nests abandoned shortly after depredation were considered to be completely depredated (i.e., entire clutch loss). To estimate inter-nest distances, we visited each nest site after all nesting birds left the island and recorded coordinates with a GPS unit. All means are provided \pm SE.

\section{Results}

We conducted $126 \mathrm{~h}$ of observations on 16 days (15 June -3 July) in 2002, and $140.5 \mathrm{~h}$ of observation on 23 days (19 June -13 July) in 2003. We observed 45 Common Eider and 10 Glaucous Gull nests in 2002, and 37 Common Eider and 9 Glaucous Gull nests in 2003. Gull nest initiation preceded eider nest initiation by several days. The majority of Glaucous Gull nests were already in the incubation stage when observations began each year, whereas the median initiation dates for Common Eiders were 23 June and 25 June, in 2002 and 2003, respectively. In both years, eider and gull nesting periods were terminated prior to hatch when a single Arctic Fox accessed the island and destroyed all nests during the incubation stage.

\section{Gull Predation}

We conducted 328 avian predator patrol watches. Glaucous Gulls were the most common predator; other avian predators (jaegers, Stercorarius spp., and Ravens, Corvus corax) were seen on only seven occasions. The search rate by gulls appeared similar each year $\left(\bar{x}_{\text {patrols/h }}=17.2 \pm 1.6\right.$ in 2002, and $14.1 \pm 1.0$ in 2003), but the search technique changed between years. In $2002,68.2 \% \pm 3.0$ of patrols were aerial, while in 2003 aerial patrols accounted for only $32.9 \% \pm 2.7$ of the total. Concurrently, the mean distance between eider nests and the nearest Glaucous Gull nest decreased significantly $\left(t_{67}=3.58, P<0.001\right)$ from $75.8 \mathrm{~m} \pm 4.3$ in 2002 to $35.2 \mathrm{~m} \pm 9.2$ in 2003 . This shift in Glaucous Gull patrols may reflect variation in the distance between Common Eider and Glaucous Gull nests between years.

Prior to the fox arrival in 2002, 42\% (19 of 45) of attempted Common Eider nests had failed and, in 2003, $70 \%$ (26 of 37) had failed but the observation period lasted 10 days longer in 2003 . The daily failure rates of 1.2 nests/day in 2002 and 1.3 nests/day in 2003 were similar. Glaucous Gull depredation was the likely cause of all of these failed nests. We directly observed Glaucous Gull depredation in 7 and 11 cases, in 2002 and 2003, respectively. Most nests were lost during the egg laying stage; however, some nests were also destroyed during incubation (4 in 2002, 10 in 2003). Proximity to gull nests appears to have been important in nest failure. Fifty percent and $75 \%$ of Common Eider nests $<30 \mathrm{~m}$ from gull nests failed in 2002 and 2003, respectively. In 2003, more nests $(n=20)$ were within $30 \mathrm{~m}$ of gull nests than in $2002(n=4)$. From the blinds, we were unable to see into nests, and thus could not quantify clutch size or proportional egg loss. Yet, in 2003 we did see 38 individual eider eggs eaten by gulls; of these, 14 were taken by Glaucous Gulls known to be nesting in the midst of the Common Eider colony (10 eggs were taken by a single pair of nesting Glaucous Gulls).

Partial predation was uncommon, as Glaucous Gulls typically removed all eggs once they gained access to a nest. We observed six cases of partial predation (4 Common Eider eggs, 2 Glaucous Gull eggs) across years. In one case, a Glaucous Gull pressured a pair of Common Eiders for $41 \mathrm{~min}$ before finally stealing an egg from beneath the hen. During this encounter, the hen never moved from the nest and did not indicate awareness of the egg loss. The attending drake actively attempted to defend the nest. In another instance, a Glaucous Gull pulled nest material from under an incubating hen, but was unable to remove any eggs. We never observed a Glaucous Gull displace a Common Eider from a nest.

Common Eiders took attendance breaks throughout the nesting period, averaging $8.2 \pm 1.3 \mathrm{~min} / \mathrm{break}$ based on 57 breaks of known length. Across years, Glaucous Gulls attempted to depredate nests during nearly one quarter (i.e., 21) of the 86 observed attendance breaks, and were successful in half of their attempts (11 of 21). Regularly, we observed Glaucous Gulls standing within $1 \mathrm{~m}$ of occupied Common Eider nests. On five of these occasions the incubating hens left their nests unattended; only two returned to successfully defend their nest.

Common Eiders showed three defense strategies against Glaucous Gulls in this study: (1) passively ignoring harassment and sitting tight on nests, (2) actively nipping/lunging at nearby gulls from occupied nests (35\% of active behaviors), and (3) actively chasing gulls from their nest after leaving it unoccupied for an 
attendance break ( $65 \%$ of active behaviors). The male Common Eider nest defense described earlier was not a singular event; rather, while attending females at nest sites, males often played an active role in defense. Male attendance of females during nest prospecting and initiation was high (for the three days prior to peak initiation in 2002 and 2003, 24\% and $71 \%$ of active nests were attended by males) then tapered through early incubation. Across years, males were involved in 13 of 15 observed nest defense events prior to 29 June and 0 of 8 defenses thereafter.

\section{Fox Predation}

In both years, a single Arctic Fox gained access to Egg Island during the incubation period. On 3 July 2002 it arrived and departed across ice floes and on 13 July 2003 it swam at least one $\mathrm{km}$ to Egg Island from a nearby island and left by swimming toward the mainland (> $2 \mathrm{~km}$ away). In both cases, the fox was responsible (directly or indirectly) for the destruction of all nests that were active at the time of arrival. The entire fox visit to Egg Island was observed in 2002 (duration $=3 \mathrm{~h} 11 \mathrm{~min}$ ) but not in 2003. When observers arrived in 2003 (after a $37 \mathrm{~h}$ absence due to weather conditions) the fox was still on the island, but all nests had been destroyed. There were 32 active nests (26 Common Eider, 6 Glaucous Gull) on the island when the fox arrived in 2002, and in 2003 there were 18 active nests (11 Common Eider, 7 Glaucous Gull) during the last observation prior to the fox visit.

When the fox arrived in 2002, there were approximately 30 non-resident Glaucous Gulls loafing on Egg Island in addition to the resident Glaucous Gulls from the six active nests. During observations in 2002, Glaucous Gulls with nearby nests attacked the fox, whereas the other gulls searched through the unprotected nests (both eider and gull) and ate the contents of all eggs encountered. Some gulls ate egg contents at the nests, but others carried eggs up to $20 \mathrm{~m}$ away before consuming them.

The fox observed in 2002 cached the vast majority of eggs that it encountered, eating only one gull egg, one eider egg, and the contents of a Snow Bunting (Plectrophenax nivalis) nest. It cached at least 34 eider and 4 gull eggs, taking on average $2.3 \mathrm{~min}$ to find an egg, cache it, and find another egg. Eggs were carried 20-100 $\mathrm{m}$ from the nest and buried 2-5 $\mathrm{cm}$ deep in areas of open sand or gravel. We do not have clutch size data from Egg Island; however, the mean Common Eider clutch size from neighboring islands in 2002 was 2.6 eggs/nest. Given this estimate, the fox took approximately $56 \%$ of the Common Eider eggs on the island, while the remaining eggs were eaten by Glaucous Gulls.

Resident Glaucous Gulls actively attacked and harassed the fox, but the fox was never seen to leave a site or egg as a result of an attack. Common Eiders never defended their nests from the fox; rather, they flushed from their nest when the fox approached to within $20 \mathrm{~m}$.

\section{Discussion}

None of the three species observed in this study appeared to have gained fitness from the use of Egg Island or from interactions on the island. In fact, it appears that they all may have fallen into a situation similar to an "ecological trap". That is, each was enticed by initial conditions (or expectation of conditions) which could have confered a fitness benefit, but due to changes in those conditions, the final result was the loss of fitness.

Glaucous Gulls nested earlier than Common Eiders and may have chosen nest sites on Egg Island in anticipation of Common Eider nests as a potential source of prey or in an attempt to avoid mammalian predators. Regardless, Common Eiders, ultimately, established their nests near existing Glaucous Gull nests. Our results suggest that proximity to Glaucous Gull nests increased avian depredation risk for Common Eiders. Similar to the results of Schamel (1977), the majority $(71 \%)$ of eider nests were depredated when located within $30 \mathrm{~m}$ of gull nests.

On the barrier islands of the central Beaufort Sea there is little vegetation, and the sparse driftwood provides minimal concealment for incubating birds (Noel et al. 2005). Female Common Eiders taking incubation breaks seem to be obvious to nearby gulls, as one-third of our observations of a Glaucous Gull predation event were apparently cued by the eider leaving for an incubation break. Although Common Eider incubation breaks were generally short and probably infrequent (Bolduc and Guillemette 2003; Swennen et al. 1993), our observations indicate that the detection of any break by a Glaucous Gull could lead to the loss of an entire clutch. Female Common Eiders generally fast through the entire nesting period (Korschgen 1977; Bolduc and Guillemette 2003; Swennen et al. 1993), but several authors have noted the physiological importance of drinking periodically throughout incubation (Bolduc and Guillemette 2003; Criscuolo et al. 2000). Thus, it appears that eider hens were forced to trade current reproductive effort for survival and future reproductive potential. It is notable that attending male Common Eiders probably did not increase nest detection substantially, as Common Eider hens were already visible to Glaucous Gulls nesting nearby, and males were, in fact, able to provide additional nest defense in several cases.

Predators, too, failed to gain a fitness benefit during this study. There was no successful Glaucous Gull reproduction in either year. As the fox and non-resident gulls were, most likely, attracted to Egg Island by the concentration of Common Eiders, it appears that Glaucous Gulls, too, fell into an "ecological trap." Common Eider nests were highly vulnerable to depredation by locally nesting Glaucous Gulls (a single nesting pair of Glaucous Gulls consumed over one quarter of all eggs we saw eaten in 2003), so it follows that Common Eider eggs were an important food 
source for breeding Glaucous Gulls on Egg Island. Yet, when unprotected eggs were most available (i.e., during the fox visit), non-resident gulls consumed the majority of eggs (including gull eggs), while breeding gulls were occupied with defense of their own nests. Ultimately, these locally breeding Glaucous Gulls failed reproductively, in spite of the apparent benefit of nesting in proximity to Common Eider nests.

Ultimately, Arctic Foxes caused the complete nest loss for all birds in this study, yet the fitness gained by the foxes was likely minimal. The foxes cached almost all the eggs and departed the island shortly after all nests were destroyed. It is doubtful that the cached eggs were ever recovered. To return to the island later in the season to retrieve cached eggs, foxes would face a longer, more arduous, swim due to continued sea ice retreat. Further, the barrier islands of the central Beaufort Sea experience substantial wave-battering and redistribution of sand and gravel from storms during the ice-free period. Thus, it is unlikely that intact cached eggs could be recovered even if the foxes returned to the island later in the season or after freeze-up.

Our results demonstrate that successful Common Eider and Glaucous Gull reproduction in the central Beaufort Sea can occur only in years when foxes do not have access to the barrier islands and even then nesting success of eiders is likely to be low (Quinlan and Lehnhausen 1982). Island access by foxes is unpredictable and can occur during any stage of nesting. These particular foxes were probably non-breeders as they were roaming the islands in July when breeders would be attending mainland dens. The number of non-breeding foxes fluctuates year-toyear; however, in the oilfields around Prudhoe Bay the degree of fluctuation has been dampened (Burgess 2000) and the number of fox dens and the average litter size have increased (Ballard et al. 2000; Burgess 2000). For this eider-gull nesting association to have evolved, the historical access of foxes to island nesting colonies must have been relatively rare (Ahlèn and Andersson 1970). These associations cannot persist on the barrier islands of the central Beaufort Sea if nesting success is consistently driven to near zero by a changed system in which the frequency of Arctic Foxes access to the islands is increased.

Despite the total nest failure caused by foxes, our observations provide information regarding rates of nest depredation by gulls in the absence of human disturbance. Gulls destroyed a fairly high proportion of nests during the egg-laying period, and some of these failed-early nests (often characterized by minimal down or nest bowl delineation) would probably go undetected by researchers searching for nests weeks later during the incubation stage. This has important implications for studies of nesting effort and success involving incubation-stage nest searches, as a bias against the detection of failed nests would lead to biased estimates of these parameters. Overall, even in the absence of human disturbance, the nesting productivity of Common Eiders on the barrier islands of the central Beaufort Sea is low due to the impact of avian and mammalian predators.

\section{Acknowledgments}

We thank J. Arnold, C. Crews, A. Farris, S. Iverson, D. Koontz, T. Pearson, L. Skerratt, S. Sonsthagen, and S. Wallace for field assistance. Particular thanks go to R. Lanctot, K. Cairns, W. Cullor, J. Sarvis, W. Streever, and ERA Helicopters, Inc., for logistical support of this project. S. Are, A. Erskine, T. Fondell, H. Wilson, and two anomynous reviews provided helpful comments on earlier versions of the manuscript. Funding was provided by the Minerals Management Service and the U.S. Geological Survey - Alaska Science Center.

\section{Literature Cited}

Ahlén, I., and Å. Andersson. 1970. Breeding ecology of an Eider population on Spitsbergen. Ornis Scandinavica 1: 83-106.

Ballard, W. B., M. A., Cronin, M. D. Robards, and E. H. Follmann. 2000. Body sizes, ages, reproductive status, and sex ratios of Arctic Foxes, Alopex lagopus, in the Prudhoe Bay Oil Field, Alaska. Canadian Field-Naturalist 114: 493494.

Bolduc, F., and M. Guillemette. 2003. Incubation constancy and mass loss in the Common Eider Somateria mollissima. Ibis 145: 329-332.

Bourget, A. A. 1973. Relation of eiders and gulls nesting in mixed colonies in Penobscot Bay, Maine. Auk 90: 809820.

Burgess, R. M. 2000. Arctic Foxes. Pages 159-178 in The Natural History of an Arctic Oil Field. Edited by J. C. Truett and S. R. Johnson. Academic Press, San Diego, California.

Criscuolo, F., M. Gauthier-Clerc, G. W. Gabrielsen, and Y. Le Maho. 2000. Recess behaviour of the incubating Common Eider Somateria mollissima. Polar Biology 23: 571-574.

Dwernychuk, L. W., and D. A. Boag. 1972. Ducks nesting in association with gulls - an ecological trap? Canadian Journal of Zoology 50: 559-563.

Fournier, M. A., and J. E. Hines. 2001. Breeding ecology of sympatric greater and lesser scaup (Aythya marila and Aythya affinis) in the Subarctic Northwest Territories. Arctic 54: 444-456.

Götmark, F., and M. Åhlund. 1988. Nest predation and nest site selection among eiders Somateria mollissima: the influence of gulls. Ibis 130: 111-123.

Johnson, S. R. 2000. Pacific Eider. Pages 259-275 in The Natural History of an Arctic Oil Field. Edited by J. C. Truett and S. R. Johnson. Academic Press, San Diego, California.

Johnson, S. R., and D. R. Herter. 1989. The Birds of the Beaufort Sea. Anchorage, Alaska: BP Exploration (Alaska) Inc. 372 pages.

Korschgen, C. E. 1977. Breeding stress of female eiders in Maine. Journal of Wildlife Management 41: 360-373.

Noel, L. E., S. R. Johnson, G. M. O'Doherty, and M. K. Butcher. 2005. Common Eider (Somateria mollissima vnigrum) nest cover and depredation on central Alaskan Beaufort Sea barrier islands. Arctic 58: 129-136. 
Quinlan, S. E., and W. A. Lehnhausen. 1982. Arctic Fox, Alopex lagopus, predation on nesting Common Eiders, Somateria mollissima, at Icy Cape, Alaska. Canadian Field-Naturalist 96: 462-466.

Schamel, D. L. 1974. The breeding biology of the Pacific Eider (Somateria mollissima v-nigra Bonaparte) on a barrier island in the Beaufort Sea, Alaska. M.S. thesis, University of Alaska, Fairbanks, Alaska.
Schamel, D. L. 1977. Breeding of the Common Eider (Somateria mollissima) on the Beaufort Sea coast of Alaska. Condor 79: 478-485.

Swennen, C., J. C. H. Ursem, and P. Duiven. 1993. Determinate laying and egg attendance in Common Eiders. Ornis Scandinavica 24: 48-52.

Received 7 March 2007

Accepted 23 May 2008 